\title{
The Role of Emotional Intelligence to Shape the Extra-Role Behaviors: Mediating effect of Emotional Labor Strategies
}

\author{
Qasim Ali Nisara*, Mamoona Nawaz ${ }^{\mathrm{b}}$, Noraini Othmana ${ }^{\mathrm{a}}$ Bidayatul Akmal Mustafa Kamila \\ aSchool of Business Management, Universiti Utara Malaysia, 06010 UUM Sintok, Kedah Malaysia \\ ${ }^{b}$ Department of Management Sciences; The Superior College Lahore, Pakistan \\ *Corresponding authors: qasim.nisar@superior.edu.pk
}

Article history: Received 25 February 2019 Received in revised form: 05 April 2019 Accepted: 28 May 2019 Published online: 29 August 2019

\begin{abstract}
Emotions are considered valuable for human experiences that regulate human actions and thoughts. Teachers' emotional intelligence and emotional labor strategies play a key role to enhance extra-role behaviors. The purpose of this study is to examine the effect of teachers' emotional intelligence on their extrarole behaviors (OCB) while concentrating on the mediating role of emotional labor strategies. Data were collected from 250 teachers of universities by applying simple random sampling technique. Moreover, the measurement model was assessed by using confirmatory factor analysis and structural equation modeling was used to test the hypotheses. The findings showed the positive relationship of teachers' emotional intelligence with their extra-role behaviors (OCB). In addition, the results portrayed that emotional labor strategies (surface acting and deep acting) mediate the association between teachers' emotional intelligence and their organizational citizenship behavior. This study gives an insight understanding regarding the crucial role of teachers' emotions to enhance their extra-role behaviors. Meanwhile, limitations of this study were also discussed with future direction.
\end{abstract}

Keywords: Emotional intelligence; emotional labor strategies; surface acting; deep acting; organizational citizenship behavior

\begin{abstract}
Abstrak
Emosi dianggap bernilai untuk pengalaman manusia yang mengawal tindakan dan pemikiran manusia. Kecerdasan emosi guru dan strategi emotional labor memainkan peranan utama untuk meningkatkan tingkah laku peranan tambahan. Tujuan kajian ini adalah untuk mengkaji kesan kecerdasan emosi guru terhadap tingkah laku peranan tambahan mereka (OCB) dengan memberi tumpuan kepada peranan perantara strategi emotional labor. Data diperolehi dari 250 guru universiti dengan menggunakan teknik pensampelan mudah rawak. Selain itu, model pengukuran dinilai menggunakan analisis faktor pengesahan dan pemodelan persamaan struktur digunakan untuk menguji hipotesis. Dapatan kajian menunjukkan hubungan positif antara kecerdasan emosi guru dengan tingkah laku peranan tambahan (OCB) mereka. Di samping itu, hasil kajian menunjukkan bahawa strategi emotional labor (lakonan permukaan dan lakonan dalaman) menjadi perantara antara kecerdasan emosi guru dan tingkah laku kewarganegaraan organisasi mereka. Kajian ini memberikan pemahaman mendalam mengenai peranan penting emosi guru untuk meningkatkan tingkah laku peranan tambahan mereka. Sementara itu, batasan kajian ini juga dibincangkan bersama dengan saranan kajian hadapan.
\end{abstract}

Kata kunci: Kecerdasan emosi; strategi emotional labor; lakonan permukaan; lakonan dalaman; tingkah laku kewarganegaraan organisasi

(C) 2019 Penerbit UTM Press. All rights reserved

\subsection{INTRODUCTION}

Emotions are considered a crucial element in teaching. Teaching professional is all connected with emotions closely related to their work and lives. It plays an important role in teacher's training and teacher development (Kafetsios \& Zampetakis, 2008; Wang, Hall, \& Taxer, 2019). Moreover, teachers have to teach in different educational institutes and have to interact with different students and have to solve their psychological problems (Khalid, Abdullah, \& Kumar M, 2012). The management of educational institutes practices some control over emotional activities of teachers by checking their performance with valuation by students and sometimes maybe by other sources. Moreover, emotions play a great role to shape the extra role behaviors. Moorman (1991) described that OCB is not a part of the employee's proper job obligation but it supports the operations of the institutes. It is an additional work that helps straight to the job and a significant factor that raises overall job performance. It is a need for organizations to work beyond formal job duties. It helps in minimizing unnecessary conflicts and extends job actions. Additionally, Mowday, Porter, and Steers (1979). It enhances enthusiasm to exert energy on behalf of the organization. The employee feels pleased to be part of the institute, and he/she wishes strongly to be a part and associated with the organization (Ghalandari, Jogh, Imani, and Nia, 2012).

Ghalandari et al. (2012) elaborated that emotional labor strategies are deemed as crucial aspects in working areas (Nisar, Othman, \& Kamil, 2018a, 2018c; Ahmad, Nisar, Imran, Waqas, \& Malik, 2019). Basically, in emotional labor employee hide their actual feelings and try to cover their emotions and work for the benefit and growth of the institute. The reason behind this act is to maximize customers and 
target clients and subordinates. Organization functioning has a significant influence on emotions labor. Individual engagement is very much important, and all roles and duties are performed by the labor. Additionally, Salovey and Mayer (1990) explained that a person who is emotionally strong could observe and control the emotions of their self and other people. It contributes to emotional management and psychological insight (Gardner 1983-1993). It helps in managing emotions, stress and health and is also helpful in managing social complexities at work. It fills the gap and maintains a better communication system. It is a key tool in interpersonal relations and also manages relationships. It increases workplace productivity, reduce stress and moderate conflicts. It also promotes understanding. It enlightens awareness and also fosters stability and continuity.

Previous studies paid less attention to integrate the teachers' emotional intelligence with their extra-role behaviors. Even with the emerging importance of emotional intelligence, few studies are available that examine EI as an antecedent of individual related outcomes (Maini et al., 2012; Meisler, 2013). Moreover, previous studies paid attention to measure the association of EI and job related outcomes directly; neglecting the underlying pathways (mediators) through which EI effect behavior (Law et al., 2004; Day and Carroll, 2004; Mikolajczak et al., 2007; Naz, Li, Nisar, \& Rafiq, 2019; Ahmad, Nisar, Aziz, \& Younus, 2019). Similarly, mediating role of teachers' emotional labor strategies was also ignored in previous studies. Therefore, the purpose of this study is to examine the crucial role of teachers' emotional intelligence towards their extra-role behaviors with the mediating effect of emotional labor strategies.

\subsection{LITERATURE REVIEW}

\section{Emotional Intelligence and Emotional Labor}

Previous studies showed a significant link between the EI and emotional labor strategies (SA \& DA) (Mikolajczak et al., 2017). DA always needs a judgment to connect emotions (Brothering and Grandey (2002). While using deep acting, employees have to understand those behaviors, emotions, and feelings after observing the reactions and emotions of the customers. These emotions are on the other hand are original emotions for better interactions. (Abraham, 2003). It is just like to deal with customers' polite manners, and it must be according to situations. We have to manage our emotions in order to alter emotional display and behavior in social interaction Lopest (2005). There is no special emotional regulation required to match organizational display rules. Broth ridge and Grandey (2002) According to (Grandey, 2005), the major deep acting is that emotions might be altered to compare the organization s display rules or to gain emotional state required to achieve organizational aims. Employees obtain emotional dissonance and provide an authentic emotional exchange with customers. Such employees who follow their emotions will be more proficient. Thus, employees need to effectively determine the proper emotions to produce positive responses from customers (Leidner, 1999). Workers need to show emotions of the service encounter just to enable successful service encounter. Mayer and Salovey (1997) employees with high EL are more effective at deep acting because they have such abilities to do something accurately. One of the previous studies depicted that emotional intelligence is deemed as a crucial element to enhance the extra role behavior of employees (Butt, Nisar, Nadeem, \& Baig, 2017).

To allow deep acting and good communication, a necessary component of excellent client service, service providers need alertness of their emotional state to decide if that state wants to change. Employees who have a higher level of emotional intelligence can handle their emotions effectively (Ahmad-Mughal, Nisar, Othman, \& Kamil, 2017; Hayyat, Nisar, Imran, \& Ikram, 2017; Khan, Imran, \& Nisar, 2016; Nisar, Othman, \& Kamil, 2018b). On the basis of above-mentioned literature, this study assumed that EI might effect to EL strategies.

\section{Emotional Intelligence, Emotional Labor Strategies and OCB}

Emotional intelligence played a crucial role in employees' organizational citizenship behavior (Carmeli, 2003; Miao, Humphrey, \& Qian, 2018; Wills, 2018). Leaders with a high level of emotional intelligence understand their followers' emotions and response them effectively as compared to leaders with a low level of emotional intelligence (Abraham, 1999). According to Irshad and Hashmi (2014), leaders' emotional intelligence, leadership styles, and organizational citizenship behavior play a crucial role in organizational success. They summed up that leaders' emotional intelligence is significantly related to employee extra-role behaviors. Moreover, another study also proved a significant and positive association between leaders' emotional intelligence and followers' organizational citizenship behavior (Florescu \& Nastase, 2014). Previous studies summed up that leaders' emotional intelligence has a significant and positive association with followers' organizational citizenship behavior (Korkmaz \& Arpac1, 2009; Modassir \& Singh, 2008; Moghadasi, Hamidi, \& Chavoshi, 2011; Sitter, 2004). This study also assumed that teachers with a higher rank of EI are capable of participating in their extra-role behaviors.

\section{Hypotheses}

H1: There is a significant and positive relationship between emotional intelligence and organizational citizenship behavior.

H2: There is a significant and negative relationship between emotional intelligence and surface acting

H3: EI is significantly and positively related to DA.

H4: Surface acting is negatively related to $O C B$.

H5: Deep acting is positively and significantly related to $O C B$.

H6: Surface acting mediates the association between EI and $O C B$.

H7: Deep acting mediates the association between EI and $O C B$. 


\section{Research Framework}

The following framework is based on theoretical foundations and empirical evidence. As shown in Figure 1, this study attempts to examine the effect of emotional intelligence on organizational citizenship behavior while concentrating on the mediating effect of emotional labor strategies.

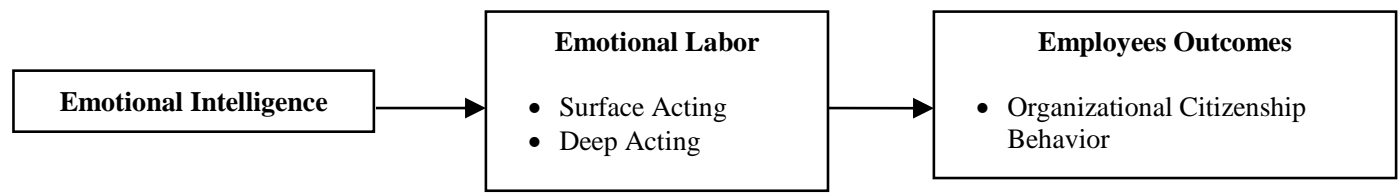

Figure 1 Theoretical framework

\subsection{METHODOLOGY}

\section{Research Design and Sample}

The quantitative research design is used in this study to judge the underlying relationship among under-study constructs. This study was descriptive and quantitative in nature. During writing results or drawing inferences about the study of population, data were analyzed and interpreted statistically at one point in time, and this study was cross-sectional. Collecting data from survey method for information is the most popular and most used method adopted in organizations (Babbie, 2005).In the study, the target population is individual teachers who are teaching in different educational institutions of Lahore Pakistan and unit of analysis was individual. Data were collected by teachers of universities by using simple random sampling technique. For collecting data for this study, the survey research method was used by selfdirected 250 questionnaires.

\section{Measures}

In the study measure and instruments which are used are valid and reliable scales. The scale used for measuring questionnaires is 5-point Likert scale. In 5-point Likert scale 1 representing "strongly disagree", 2 signifying "disagree", 3 shows "neutral", 4 signifying "agree" and "5 representing "strongly agree" state of mind. As emotional labor is divided into two sub-variables, so surface \& deep acting are measured by 7 items and 4 items "I place on a "show" or "performance" when interacting with subordinates" from Diefendorff et al., 2005, Emotional intelligence is measured by 16 items "I really understand what I feel". Moreover, that scale is developed by Wong \& Law (2002). A scale by May, Gilson, and Harter (2004) which consists of 4 items is used to measure the followers' emotional engagement. A sample item is " $I$ put my heart into my job".

\subsection{FINDINGS}

As shown in Table 1 the factor loadings, composite reliability and average variance extract that are used to check the conconvergent validity of constructs. The validity of a construct is said to be convergent when indicators/items load highly (i.e., $>0.50$ ) on their associated constructs (Hair et al., 2010). As indicated in Table 7, all the indicators were weighted down on their respective constructs from a lower bound of 0.590 to an upper bound of 0.852 . Construct the convergent validity of and measured by using average variance extract and composite reliability. The rule of thumb is that an AVE value of 0.50 or greater is considered satisfactory (Barclay et al., 1995). The AVE value is above 0.50 for all constructs, and composite reliability is greater than 0.8 , demonstrating that the convergent validity of all constructs has been established.

Table 1 Confirmatory factor analysis

\begin{tabular}{lccccc}
\hline Constructs & Items & Loadings & Alpha & CR & AVE \\
\hline \multirow{2}{*}{ Emotional Intelligence } & & & 0.88 & 0.9 & 0.5 \\
& EI1 & 0.70 & & & \\
EI2 & 0.76 & & & \\
EI3 & 0.76 & & & \\
EI4 & 0.73 & & & \\
EI5 & 0.70 & & & \\
& EI6 & 0.70 & & & \\
EI7 & 0.65 & & & \\
& EI8 & 0.68 & & & \\
EI9 & 0.69 & & & \\
Surface Acting & SA1 & 0.79 & 0.79 & 0.85 & \\
& SA2 & 0.75 & & &
\end{tabular}




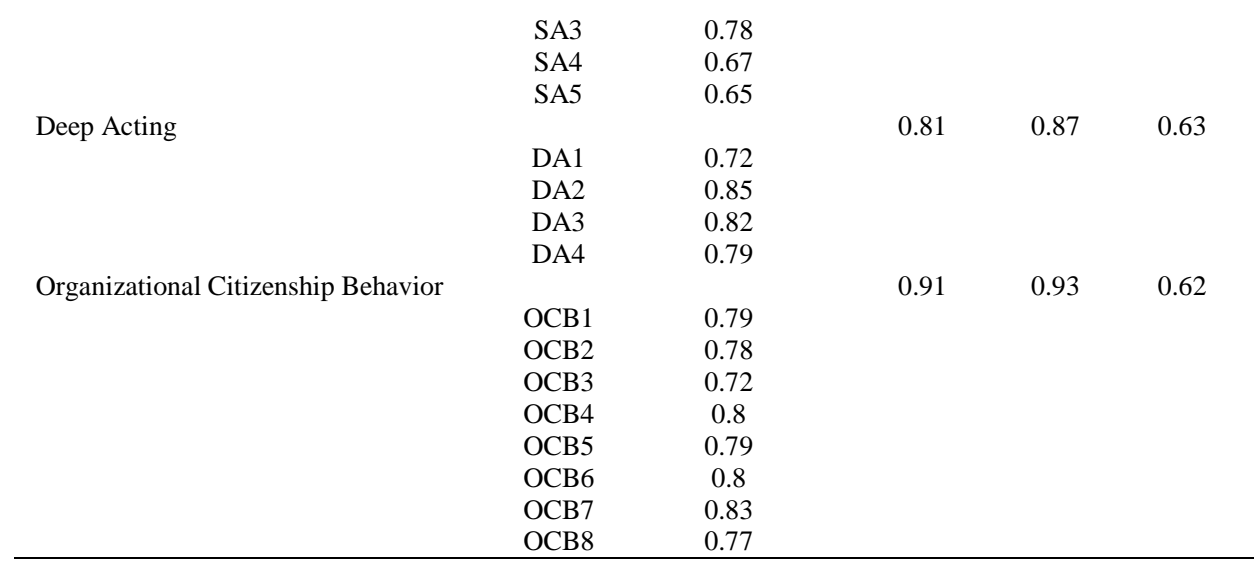

Table 2 described the discriminant validity by using HTMT ratio. As Gold et al. (2001) defined that HTMT ratio must be less than 0.90 to confirm the discriminate validity and results showed that all the values of HTMT ratio are less that 0.90 that indicated that discriminant validity is established.

Table 2 Heterotrait-monotrait ratio

\begin{tabular}{ccccc}
\hline Constructs & DA & EI & OCB & SA \\
\hline DA & & & & \\
EI & 0.35 & & & \\
OCB & 0.44 & 0.58 & & \\
SA & 0.43 & 0.21 & 0.29 & \\
\hline
\end{tabular}

Note: $\mathrm{EI}=$ Emotional intelligence; $\mathrm{DA}=$ Deep acting; $\mathrm{OCB}=$ Organizational citizenship behavior; $\mathrm{SA}=$ Surface acting

\section{Structure Equation Modeling (SEM)}

Structure equation modeling technique was used to test the relationship between constructs. Refer to Table 3, EI is significantly and positively connected to $\mathrm{OCB}(\beta=0.45, \mathrm{t}=5.87)$ and supported to H1. Correspondingly, EI is significantly and negatively related to SA $(\beta=0.22, \mathrm{t}=$ 2.09 ) and not supported to $\mathrm{H} 2$. Additional, as shown in Table 3 , EI is significantly and positively related to DA $(\beta=0.33, \mathrm{t}=3.88)$ and supported to H4 Significantly and positively related to DA $(\beta=0.33, t=3.88)$ and supported to H3. SA is negative. SA is significantly mediate the relationship between OCB $(\beta=0.1, \mathrm{t}=0.89)$ and not supported to H4. DA is positively and significantly related to OCB $(\beta=$ $0.22, \mathrm{t}=2.73$ ) and supported to $\mathrm{H} 5$.

Table 3 Direct effect

\begin{tabular}{cccccccc}
\hline Hypothesis & Relationship & $\begin{array}{c}\text { Std. } \\
\text { Beta }\end{array}$ & $\begin{array}{c}\text { Std } \\
\text { error }\end{array}$ & t-Value & Decision & $\mathbf{R}^{2}$ & $\mathbf{f}^{2}$ \\
\hline H1 & EI -> OCB & 0.45 & 0.07 & 5.87 & Supported & 0.34 & 0.26 \\
H2 & EI -> SA & 0.22 & 0.09 & 2.09 & Supported & 0.04 & 0.04 \\
H3 & EI -> DA & 0.33 & 0.08 & 3.88 & Supported & 0.10 & 0.11 \\
H4 & SA -> OCB & 0.10 & 0.09 & 0.89 & Not Supported & & 0.01 \\
H5 & DA -> OCB & 0.22 & 0.08 & 2.73 & Supported & & 0.23 \\
\hline
\end{tabular}

Bootstrapping procedure was used to assess the indirect effects. Findings of Table 4 also revealed that surface acting mediates the relationship between EI and OCB $(\beta=0.07, \mathrm{t}=1.75)$ and $\mathrm{H} 6$ is supported. Results also purposed that DA also significantly mediates the relationship EI and $\mathrm{OCB}(\beta=0.09, \mathrm{t}=4.50)$ and support to $\mathrm{H} 7$. 
Table 4 Mediating role of emotional labor

\begin{tabular}{cccccccc}
\hline H & Relationship & $\begin{array}{c}\text { Std. } \\
\text { Beta }\end{array}$ & $\begin{array}{c}\text { Std. } \\
\text { Error }\end{array}$ & t-Value & $\begin{array}{c}\text { Lower } \\
\text { Limit }\end{array}$ & $\begin{array}{c}\text { Upper } \\
\text { Limit }\end{array}$ & Decision \\
\hline H6 & EI -> SA -> OCB & 0.07 & 0.04 & 1.75 & 0.02 & 2.34 & Supported \\
H7 & EI -> DA -> OCB & 0.09 & 0.02 & 4.50 & 0.45 & 3.55 & Supported \\
\hline
\end{tabular}

\subsection{DISCUSSION AND CONCLUSION}

The primary and foremost reason for conducting this study was to enlighten the crucial role of EI and emotional labor strategies to shape the employees' extra-role behaviors. After the study, findings of this study showed and proved that emotional intelligence and emotional labor strategies are significantly related to employees extra-role behaviors. Results proved that EI is significantly and positively related to OCB supported to H1. These findings are aligned with previous studies (Groves \& Vance, 2007; Miao, Humphrey, \& Qian, 2016). Moreover, EI is significantly and negatively related to SA and H2 is not supported by SA (Bozionelos \& Kiamou, 2008; Rafaeli \& Sutton, 1987). Meanwhile, emotional intelligence is also significantly and positively related to deep acting and supported to H3 (Kafetsios \& Zampetakis, 2008; Pienaar \& Willemse, 2008). Findings of this study also identified that surface acting is significantly mediates the relationship between EI and OCB and supported to H6. DA is positively and significantly related to OCB and supported H5 (Uppala et al., 2005). DA is also significantly mediated the relationship between EI and OCB and also supported to H7 (Miao et al., 2016; Stemmler, 1997).

This study contributed to the literature of emotional intelligence, emotional labor, and behavioral outcomes. It contributed to the literature of emotional labor by investigating the mediating role of emotional labor. Prior studies on emotional labor focused on the intrapersonal impact of emotional labor (Wang et al., in press; Cote, 2005) but this study creates a link between teachers' emotional labor strategies and outcomes. It also supported the emotional labor theory (Grandey, 2000) and attaches it with leadership literature.

\subsection{PRACTICAL IMPLICATIONS}

This study has significant practical implications regarding managerial perspectives. It revealed that teachers could make use of EI and EL strategies to positively influence their students. It provides an insight understanding of the role of emotional labor in educational institutions. Teachers need to understand that in which scenario they have to use which form of emotional labor strategies. Teachers can choose any specific form of emotional labor according to their desired performance outcomes. Educational institutions can reduce the stress of job and exhaustion of emotions of employees by effective execution of current results. This study also helped management people to manage their human resources effectively. As study propose that deep acting significantly associated with followers' job satisfaction, so institutions can put efforts to develop and polish teachers' deep acting skills by organizing effective HRM training programs. The organizations can arrange emotional competences trainings to polish the teachers' deep acting skills (Grandey. 2003; Brotheridge, 2006a). It also proposed surface acting as a reactive approach and deep acting deemed to be a proactive approach, so the organizations can develop, polish and promote the deep acting skills rather than surface acting during training sessions. In addition, these emotional labor strategies (deep acting, display of naturally felt emotions) deemed to be a very beneficial tool to improve the teachers' level of satisfaction. Training programs regarding teachers' emotional labor strategies and especially deep acting training could be helpful to stop the burnout in employees (Grandey, 2003; Brotheridge, 2006a) and due to these training programs teachers can perform their responsibilities efficiently. Organizations should concentrate during emotional competency trainings that which type of emotional labor strategy leaders should use in different situations to gain more accurate and valuable results. It also helpful for universities to recognize the importance and difference between different emotional labor strategies and they can align these strategies with organizational goals (Boss \& Sims, 2008). Moreover, teachers with emotional intelligence abilities can make room for mental and physical space for the emotions ventilation at the workplace (Haver et al., 2013). It gives way to organizations to spend in training their leaders concerning the effective management of their emotions with theoretical and realistic perspectives. Just because of trainings, an organization can also build up the basic abilities and skills to convey naturally felt emotion which can leads to get better job performance (Ong et al., 2006).

\subsection{LIMITATIONS AND FUTURE DIRECTION}

In this study, there are some gaps and limitations which need to address for better results in future. A sample size of the current study was small due to financial and non-financial constraints that lead to results that were inaccurate, therefore if the sampling size frame of this study increase in future can find better, accurate and more reliable results for further studies in future. Data were collected by applying random sampling technique and in future researchers can adopt other techniques of probability sampling to have a clear and obvious picture. This study was based on methods that are descriptive and quantitative in nature, and it ignored the qualitative and mixed methodological approach. Further studies can use a mixed and qualitative approach to improve the conceptual understanding and accepting of emotional labor strategies in a leadership context. A major limitation of this study is sample size. The response rate of respondents was minor in this study. So the standpoint of the entire sector is missing. There are other sectors in which research can be conducted in the future. This study was limited only to the Educational sector. There is very less research conducted in the past as a moderating role of emotional labor, so there is a gap in that. In future research can be conducted on that topic too. This study also focused on educational sectors of Lahore Pakistan so it can be conducted on other areas of Pakistan in the future. 


\section{References}

Ahmad-Mughal, S., Nisar, Q. A., Othman, N., \& Kamil, B. A. M. (2017). Do Emotional Intelligence \& Organizational Politics influence Employee Work Behaviors and attitudes? Mediating Role of Political Skill. Jurnal Pengurusan, 51, 261-271.

Ahmad, S., Nisar, Q. A., Imran, A., Waqas, M., \& Malik, S. (2019). Linking leader's Emotional Labour Strategies With Leader's Attitude: An Effective Approach Towards Leadership. Middle East J, 6(2), 139-153.

Ahmad, S., Nisar, Q. A., Aziz, K., \& Younus, S. (2019). The role Of Organisational Socialisation Tactics And Task Characteristics Toward Turnover Intentions: Mediating Role Of Job Embeddedness. Middle East Journal of Management, 6(1), 75-94.

Babbie, E. (2005). Improving the Measurement of Public Opinion. The Illusion of Public Opinion: Fact and Artifact in American Public Opinion Polls, 187.

Bozionelos, N., \& Kiamou, K. (2008). Emotion work in the Hellenic Frontline Services Environment: How It Relates To Emotional Exhaustion And Work Attitudes. The International Journal of Human Resource Management, 19(6), 1108-1130.

Butt, S. S., Nisar, Q. A., Nadeem, S., \& Baig, F. (2017). Longitudinal study To Examine The Influence Of Emotional Intelligence On Organizational Citizenship Behavior: Mediating Role Of Political Skills. WALIA Journal, 33(1), 54-63.

Ghalandari, K., Jogh, M. G. G., Imani, M., \& Nia, L. B. (2012). The effect Of Emotional Labor Strategies On Employees Job Performance And Organizational Commitment In Hospital Sector: Moderating Role Of Emotional Intelligence In Iran. World Applied Sciences Journal, 17(3), 319-326.

Groves, K. S., \& Vance, C. M. (2007). Examining Thinking Style, EQ, And Organizational Commitment In The Context Of Emotional Labor. Paper Presented at the Academy of Management Proceedings.

Hayyat, U., Nisar, Q. A., Imran, M., \& Ikram, M. (2017). Consequences of Emotional Labor in Health Sector of Pakistan. International Journal For Research In Business, Management And Accounting, 3(6), 64-79.

Khalid, K., Abdullah, H. H., \& Kumar M, D. (2012). Get Along With Quantitative Research Process. International Journal of Research in Management, 2(2), 15-29.

Khan, N. Z. A., Imran, A., \& Nisar, Q. A. (2016). Emotional Exhaustion as Stressor agent for Job Stress in Call Centers: Empirical evidence from perspective of Job Satisfaction and Turnover Intention as Work Outcomes. European Online Journal of Natural and Social Sciences, 5(4), 908.

May, D. R., Gilson, R. L., \& Harter, L. M. (2004). The psychological Conditions Of Meaningfulness, Safety And Availability And The Engagement Of The Human Spirit At Work. Journal of Occupational and Organizational Psychology, 77(1), 11-37.

Miao, C., Humphrey, R. H., \& Qian, S. (2018). A cross-Cultural Meta-Analysis Of How Leader Emotional Intelligence Influences Subordinate Task Performance And Organizational Citizenship Behavior. Journal of World Business, 53(4), 463-474.

Miao, C., Humphrey, R. H., \& Qian, S. (2016). Leader emotional Intelligence And Subordinate Job Satisfaction: A Meta-Analysis Of Main, Mediator, And Moderator Effects. Personality and Individual Differences, 102, 13-24.

Naz, S., Li, C., Nisar, Q. A., \& Rafiq, M. (2019). Linking Emotional Intelligence To Knowledge Sharing Behaviour: Mediating Role Of Job Satisfaction And Organisational Commitment. Middle East Journal of Management, 6(3), 318-340.

Nisar, Q. A., Othman, N., \& Kamil, B. A. M. (2018a). Leaders' Emotional Labor Strategies and Wellbeing: Does Perceived Organizational Justice Mediates the Relationship. Pakistan Journal of Humanities and Social Sciences, 6(1), 82-98.

Nisar, Q. A., Othman, N., \& Kamil, B. A. M. (2018b). Leaders' Emotional Labor Strategies and Wellbeing: Does Perceived Organizational Justice Mediates the Relationship? Pakistan Journal of Humanities and Social Sciences, 6(1), 82-98.

Nisar, Q. A., Othman, N., \& Kamil, B. A. M. (2018c). Leaders' Emotions and Followers' Behaviors: A New Perspective with Perceived Emotional Sincerity.

Pienaar, J., \& Willemse, S. A. (2008). Burnout, engagement, Coping And General Health Of Service Employees In The Hospitality Industry. Tourism Management, 29(6), 1053-1063.

Rafaeli, A., \& Sutton, R. I. (1987). Expression of Emotion As Part Of The Work Role. Academy Of Management Review, 12(1), 23-37.

Stemmler, G. (1997). Selective activation Of Traits: Boundary Conditions For The Activation Of Anger. Personality and Individual Differences, 22(2), 213-233.

Uppala, S. M., Kållberg, P., Simmons, A., Andrae, U., Bechtold, V. d., Fiorino, M., Kelly, G. (2005). The ERA- 40 re- Analysis. Quarterly Journal Of The Royal Meteorological Society, 131(612), 2961-3012.

Wang, H., Hall, N. C., \& Taxer, J. L. (2019). Antecedents and Consequences of Teachers' Emotional Labor: a Systematic Review and Meta-analytic Investigation. Educational Psychology Review, 1-36.

Wills, A. (2018). Emotional and Spiritual Intelligence In The Workplace In Relation To Organizational Citizenship Behavior(Doctoral dissertation, Kaplan University). 